\title{
Celtis sinensis Pers. (Ulmaceae) naturalised in northern South Africa and keys to distinguish between Celtis species commonly cultivated in urban environments
}

\begin{tabular}{|c|c|}
\hline \multicolumn{2}{|c|}{$\begin{array}{l}\text { Authors: } \\
\text { Stefan J. Siebert }{ }^{1} \text { (D) } \\
\text { Madeleen Struwig }^{1,2,3} \\
\text { Leandra Knoetze }^{1} \text { (I) } \\
\text { Dennis M. Komape }^{1}\end{array}$} \\
\hline \multicolumn{2}{|c|}{$\begin{array}{l}\text { Affiliations: } \\
{ }^{1} \text { Unit for Environmental } \\
\text { Sciences and Management, } \\
\text { North-West University, } \\
\text { South Africa }\end{array}$} \\
\hline \multicolumn{2}{|c|}{$\begin{array}{l}{ }^{2} \text { Department of Soil, Crop } \\
\text { and Climate Sciences, } \\
\text { University of the Free State, } \\
\text { South Africa }\end{array}$} \\
\hline \multicolumn{2}{|c|}{$\begin{array}{l}{ }^{3} \text { Department of Botany, } \\
\text { National Museum, } \\
\text { South Africa }\end{array}$} \\
\hline \multicolumn{2}{|c|}{$\begin{array}{l}\text { Corresponding author: } \\
\text { Stefan Siebert, } \\
\text { stefan.siebert@nwu.ac.za }\end{array}$} \\
\hline \multicolumn{2}{|c|}{$\begin{array}{l}\text { Dates: } \\
\text { Received: } 07 \text { Aug. } 2017 \\
\text { Accepted: } 15 \text { Nov. } 2017 \\
\text { Published: } 29 \text { Mar. } 2018\end{array}$} \\
\hline \multicolumn{2}{|c|}{$\begin{array}{l}\text { How to cite this article: } \\
\text { Siebert, S.J., Struwig, M., } \\
\text { Knoetze, L. \& Komape, D.M., } \\
2018, \text { 'Celtis sinensis Pers. } \\
\text { (Ulmaceae) naturalised in } \\
\text { northern South Africa and } \\
\text { keys to distinguish between } \\
\text { Celtis species commonly } \\
\text { cultivated in urban } \\
\text { environments', Bothalia } \\
\text { 48(1), a2288. https://doi. } \\
\text { org/10.4102/abc.v48i1.2288 }\end{array}$} \\
\hline \multicolumn{2}{|c|}{$\begin{array}{l}\text { Copyright: } \\
\text { (C) 2018. The Authors } \\
\text { Licensee: AOSIS. This } \\
\text { is licensed under the } \\
\text { Creative Commons } \\
\text { Attribution License. }\end{array}$} \\
\hline \multicolumn{2}{|l|}{ Read online: } \\
\hline 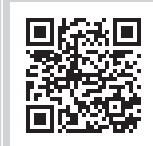 & $\begin{array}{l}\text { Scan this QR } \\
\text { code with your } \\
\text { smart phone or } \\
\text { mobile device } \\
\text { to read online. }\end{array}$ \\
\hline
\end{tabular}

Background: Alien Celtis species are commonly cultivated in South Africa. They are easily confused with indigenous C. africana Burm.f. and are often erroneously traded as such. Celtis australis L. is a declared alien invasive tree. Celtis sinensis Pers. is not, but has become conspicuous in urban open spaces.

Objectives: This study investigates the extent to which $C$. sinensis has become naturalised, constructs keys to distinguish between indigenous and cultivated Celtis species, and provides a descriptive treatment of $C$. sinensis.

Methods: Land-cover types colonised by $C$. sinensis were randomly sampled with 16 belt transects. Woody species were identified, counted and height measured to determine the population structure. C. africana and the three alien Celtis species were cultivated for 2 years and compared morphologically.

Results: Celtis sinensis, Ligustrum lucidum and Melia azedarach were found to be alien species, most abundant in urban areas. The population structure of $C$. sinensis corresponds to that of the declared invasive alien, $M$. azedarach. Although $C$. africana occurs naturally, it is not regularly cultivated. This is ascribed to erroneous plantings because of its resemblance to juvenile plants of $C$. sinensis. Keys are provided to identify Celtis species based on leaf shape and margin, and drupe characters.

Conclusion: Celtis sinensis is naturalised in central South Africa, especially in urban open spaces and beginning to colonise natural areas. It is flagged as a species with invasive potential. Characteristics of the leaves and fruits allow for accurate identification of indigenous and alien Celtis species, both as juvenile or adult trees.

\section{Introduction}

Invasive organisms are considered to be one of the most important threats to biodiversity worldwide (Vitousek et al. 1997) and costs South Africa millions of rands annually to control (Le Maitre et al. 2002). Southern Africa's current concerns with invasive plants were already predicted in the 1960s and the 1970s (Stirton 1978; Wild 1961), fully recognised and documented in the 1980s (Henderson et al. 1987; Wells et al. 1986) and flagged, and their invasiveness categorised, since the 1990s (Henderson 2001; Henderson \& Cilliers 2002).

Urban areas are seed pools for potentially invasive alien plants, as these species are cultivated as garden subjects in mass and propagules escape from there to become naturalised in natural areas, but especially along disturbed water courses and roadsides (Horvitz et al. 2014; Kalwij et al. 2008). Naturalised species are capable of reproducing and spreading without direct assistance by people, and the most aggressive species become invaders capable of penetrating and replacing indigenous vegetation and threatening indigenous biodiversity (Ndhlovu, Milton \& Esler 2016). Hence, the number of species becoming invasive increases annually (Seebens et al. 2017) and threatens agricultural productivity, water resources and natural ecosystems, with temperate agricultural or urban sites among the areas most invaded by alien plants (Lonsdale 1999).

Although C. australis L. and C. occidentalis L. have been included in South Africa's NEM:BA list of invasive species as Category 3 (Department of Environmental Affairs 2014), C. sinensis Pers. is generally considered to be naturalised, but not invasive (Henderson 2001). In cities of the northern provinces of South Africa, C. sinensis is the preferred tree for street plantings and is a regular feature in domestic gardens, parks and parking lots because of its dense foliage, fast growth rate 
and ability to withstand the harsh winters on the Highveld (Lubbe, Siebert \& Cilliers 2011).

Phytosociological studies of urban areas conducted in the 1990s hardly reported any individuals of C. sinensis (Cilliers \& Bredenkamp 1999), and subsequently, it was highlighted as an emerging invader by Mgidi et al. (2007). In recent years, C. sinensis (which originates from China, Japan and Korea) has become very conspicuous in urban open spaces, roadsides and riparian areas on the Highveld. Celtis sinensis also poses a major threat to the indigenous $C$. africana Burm.f., as it and the closely related $C$. australis hybridise readily with the former in Gauteng (Glen \& Van Wyk 2016). In a study by Whittemore and Townsend (2007) on the hybridisation potential of Celtis species, C. sinensis was one of the species that tested positive for this ability. Buck and Bidlack (1998) found that data sets of morphological and isozymic data demonstrate congruity among Celtis species, which is ascribable to hybridisation.

Three of the eight African Celtis species are indigenous to southern Africa, namely the widespread C. africana (white stinkwood), C. gomphophylla Baker (false white stinkwood) in the Eastern Cape and KwaZulu-Natal, and C. mildbraedii Engl. (Natal white stinkwood) in KwaZulu-Natal and Swaziland (Pooley 1997). Three alien Celtis species from temperate regions are commonly cultivated in South Africa (Kuruneri-Chitepo \& Shackleton 2011; Lubbe et al. 2011; Molebatsi, Siebert \& Cilliers 2013), namely C. australis (nettle tree) from southern Europe and western Asia, C. occidentalis (hackberry) from northern USA and Canada, and C. sinensis (Chinese nettle tree), all of which are easily confused with C. africana in the juvenile stage. Celtis sinensis is especially cultivated extensively in urban environments, as it is readily available from nurseries where it is sold as 'stinkwood', creating the impression that it is the indigenous C. africana because of morphological similarities.

This article investigates the extent to which $C$. sinensis has become naturalised in urban open spaces and surrounding agricultural areas in the central part of northern South Africa. Celtis sinensis is not a declared alien invasive tree in South Africa, and this article compares its population data with that of an indigenous (C. africana) and declared alien tree species (Melia azedarach L.) from similar urban and agricultural environments in the Tlokwe Municipal area. A key is provided to distinguish between the indigenous and cultivated Celtis species of northern South Africa, and a simple key for quick identification of juvenile Celtis individuals sold at nurseries. A taxonomic treatment of $C$. sinensis is provided for the species to be officially included in the southern African flora as naturalised.

\section{Material and methods Distribution and population data}

Distribution records were obtained from the National Museum in Bloemfontein (NMB), National Herbarium in Pretoria (PRE), H.G.W.J. Schweickerdt Herbarium (PRU),
A.P. Goossens Herbarium (PUC) and the South African Plant Invaders Atlas database (Henderson 1998).

Cultivation records of trees were extracted from a garden database comprising frequency data for 256 gardens surveyed in Ganyesa, Potchefstroom and Roodepoort (Davoren et al. 2016). Three land-cover types (riparian, rangelands and urban open space) were identified within a $60 \mathrm{~km}$ radius of Potchefstroom, and 16 belt transects per land-cover were sampled. Transects were $50 \mathrm{~m} \times 5 \mathrm{~m}$, and every woody species within each transect was identified up to species level, counted and the height measured with a clinometer. Land-cover type data were supplemented with frequency data from 16 belt transects from domestic gardens (Davoren et al. 2016) and included in the study for comparative purposes.

Height class distributions were compiled for each species. Sturge's rule was applied (Scott 2009) to determine the sizeclass distribution and frequency intervals for the population graphs. Stability between successive size classes was determined with quotient analysis (Botha, Witkowski \& Shackleton 2004). The likelihood that any two trees within a population originate from the same size-class was assessed by Simpson's Index of Dominance (SDI) (Venter \& Witkowski 2010). Permutation Index (PI) was calculated for each species to calculate the degree of deviation from a monotonic decline or from an inverse-J curve (Wiegand et al. 2000).

\section{Juvenile morphology}

Seeds were collected from correctly identified C. africana, C. australis, C. occidentalis and C. sinensis in the field and germinated at the North-West University Botanical Garden. Plants were maintained under identical nursery conditions for 3 years in terms of watering, fertiliser additions and percentage shade. The length and width of the petiole, leaf and fruit of six plants per species were measured (plants $<1.5 \mathrm{~m}$ in height).

\section{Results and discussion Cultivation and naturalisation patterns}

Celtis sinensis occurs as a garden subject throughout South Africa and is one of the ten most widely cultivated species in our sample of Highveld gardens (third overall, Table 1). It is also very popular as a street tree. Celtis sinensis is the only alien tree in the top five that is not a fruit tree, suggesting that its popularity lies elsewhere, probably its hardiness, fast growth, dense shade, resistance to pollution and being deciduous (letting the sun through in the winter) (Glen \& Van Wyk 2016). These are also the characteristics that make Vachellia karroo a popular indigenous garden subject (Joffe 2001; Table 1). It is important to note that the indigenous C. africana is less popular as a garden subject compared to C. sinensis (Table 1).

Celtis sinensis is more popular as a garden subject than all but one declared alien invasive species, namely Morus alba (Table 1). 
TABLE 1: Ten most frequently recorded tree species during a survey of 256 gardens on the Highveld

\begin{tabular}{|c|c|c|c|}
\hline Species & Family & Gardens (\%) & Invasive category \\
\hline Prunus persica & Rosaceae & 59 & None \\
\hline Morus alba $\dagger$ & Moraceae & 39 & 3 \\
\hline Celtis sinensisł & Ulmaceae & 28 & None \\
\hline Vachellia karroo & Fabaceae & 27 & - \\
\hline Prunus armeniaca $\dagger$ & Rosaceae & 24 & None \\
\hline Ziziphus mucronata & Rhamnaceae & 21 & - \\
\hline Melia azedarach $\dagger$ & Meliaceae & 17 & 3 \\
\hline Lagerstroemia indica $\dagger$ & Lythraceae & 16 & None \\
\hline Celtis africana & Ulmaceae & 14 & - \\
\hline Robinia pseudoacacia $\dagger$ & Fabaceae & 13 & $1 \mathrm{~b}$ \\
\hline
\end{tabular}

Source: Davoren, E., Siebert, S.J., Cilliers, S.S. \& Du Toit, M.J., 2016, 'Influence of socioeconomic status on design of Batswana home gardens and associated plant diversity patterns in northern South Africa', Landscape and Ecological Engineering 12, 129-139. https://doi.org/10.1007/s11355-015-0279-x

$\dagger$, denotes alien species. Invasive categories are according to NEM:BA (Department of Environmental Affairs 2014).

TABLE 2: Ten tree species most frequently recorded during the survey of 48 transects (garden data excluded).

\begin{tabular}{llcc}
\hline Species & Family & Transects (\%) & Invasive category \\
\hline Searsia pyroides & Anacardiaceae & 49 & - \\
Vachellia karroo & Fabaceae & 41 & - \\
Celtis africana & Ulmaceae & 39 & - \\
Melia azedarach $\dagger$ & Meliaceae & 32 & 3 \\
Searsia lancea & Anacardiaceae & 27 & - \\
Gymnosporia buxifolia & Celastraceae & 25 & - \\
Celtis sinensis† & Ulmaceae & 22 & None \\
Ziziphus mucronata & Rhamnaceae & 20 & - \\
Ehretia rigida & Boraginaceae & 19 & - \\
Ligustrum lucidum $\dagger$ & Oleaceae & 18 & $1 \mathrm{~b}$ \\
\hline
\end{tabular}

$\dagger$, denotes alien species. Invasive categories are according to NEM:BA (Department of Environmental Affairs 2014).

The survey of land-cover types (urban open space, riparian areas and rangelands) revealed that $M$. alba, despite its wide cultivation, was not the most common alien of non-cultivated areas, but instead C. sinensis, Ligustrum lucidum and Melia azedarach were recorded more frequently (Table 2). Celtis sinensis and $M$. azedarach were the only alien trees in both the top ten lists for most frequently cultivated (Table 1) and naturally occurring (Table 2) species. Melia azedarach is a declared invasive alien and is no longer available in the nursery trade because of its weedy nature and public awareness (Henderson 2007).

Celtis africana, one of the only three indigenous tree species that naturally occur more frequently than $M$. azedarach and one of the five tree species found more frequently than $C$. sinensis, is commonly found across all the sampled land-cover types (Table 2). Celtis africana is not common in gardens because of $C$. sinensis being most available from nurseries. Celtis africana is very common in natural areas, with $>60 \%$ of the surveyed population recorded from rangeland, hills and ridges (Figure 1). Melia azedarach is also not commonly cultivated and is most commonly found in urban open space (> $40 \%$ of the population). More than $60 \%$ of the recorded $C$. sinensis individuals were from gardens, with the rest found in urban open space, riparian areas and rangelands in descending order (Figure 1). Celtis sinensis is definitely spreading from urban



FIGURE 1: Percentage of total number of recorded individuals of Celtis sinensis across land-cover types compared to a co-occurring indigenous relative (Celtis africana) and an invasive alien (Melia azedarach)

areas outward, typically following the predicted pathway along watercourses and roads (Milton \& Dean 1998). This adaptability can be ascribed to its ability to withstand heavy winter frosts, fleshy fruits that are prone to bird dispersal and lack of competition in a predominantly treeless Highveld landscape.

\section{Population structure}

Limited variation in the quotient $(0.2-0.8)$ is indicative of a stable population for C. africana (Figure 2a) (Botha et al. 2004; Shackleton 1993). The fluctuating quotient for C. sinensis (0.1-1.2) is interpreted as instability within the height classes of the specific population probably because of erratic colonisation and survival events (Figure 2b). However, the comparatively little variation (0-0.8) detected for M. azedarach indicates that the population structure is stable because of the longer time it has had to establish since naturalisation (Figure 2c).

None of the populations had SDI values below 0.1 , revealing that size frequency is steeper than would be expected from an exponentially declining population (Botha et al. 2004). In this case, the two Celtis species have the same SDI (0.66) and lower than $M$. azedarach (0.86). In all three cases, this is an indication that individuals are not evenly distributed among the size classes, but this needs to be considered with PI values that are based on the assumption that an ideal undisturbed population should represent a monotonic decline $(\mathrm{PI}=0)$. This is typical for C. africana, but not for $C$. sinensis $(\mathrm{PI}=4)$ and $M$. azedarach ( $\mathrm{PI}=2$ ), which have discontinuous populations, where larger individuals show a higher frequency than a previous size-class (Botha et al. 2004; Venter \& Witkowski 2010).

Overall, the population structure of $C$. sinensis is most similar to that of the invader ( $M$. azedarach) and not the related, indigenous species (C. africana). The $C$. sinensis population 

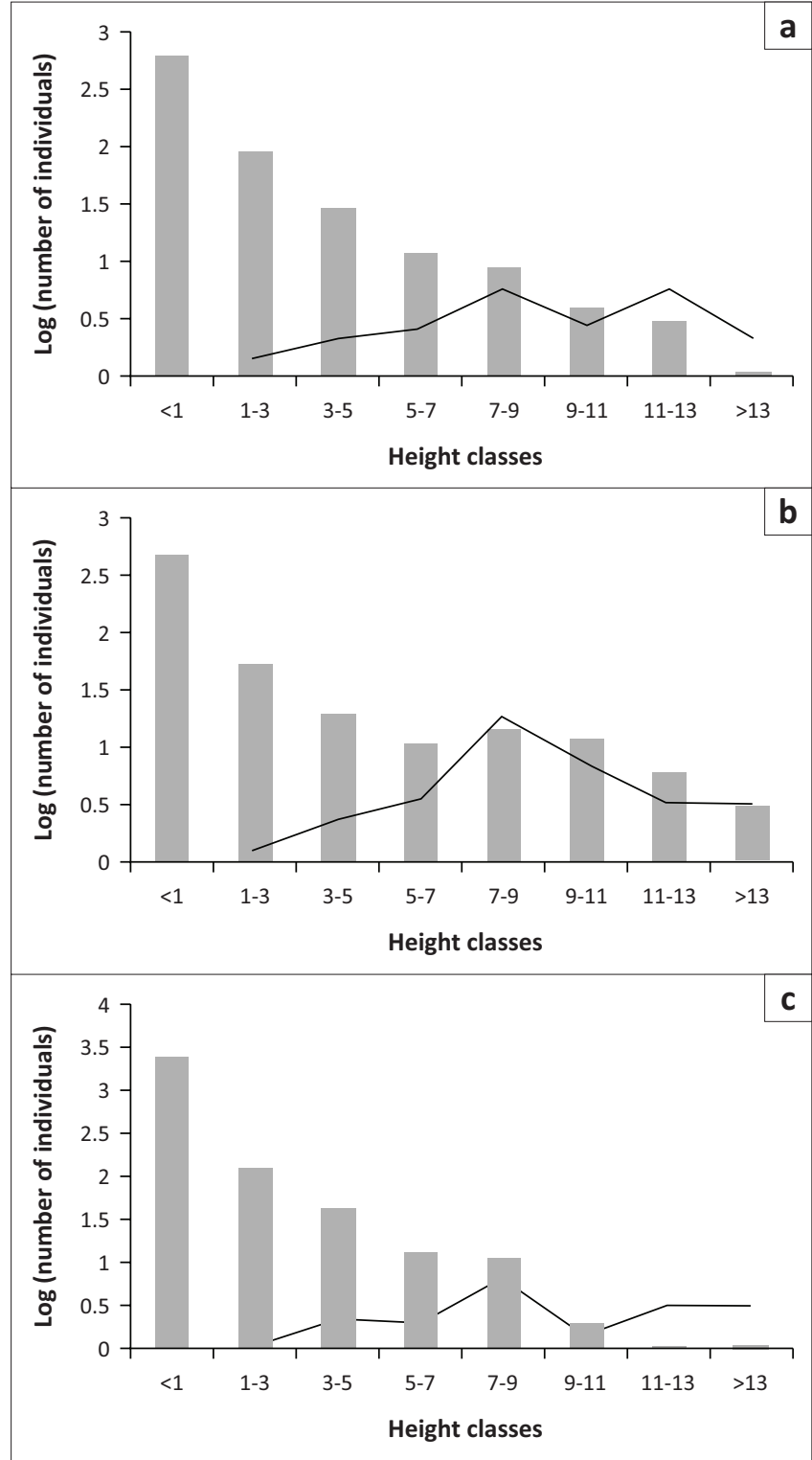

FIGURE 2: Height classes (log transformed) and quotient analyses (solid black line) of (a) Celtis africana, (b) Celtis sinensis and (c) Melia azedarach.

has more individuals than C. africana in the taller height classes, which is indicative of successful establishment, and the high numbers of saplings show the ability to reproduce (Table 3). This is an indication that $C$. sinensis is successfully increasing by reproducing and establishing in the environment. In the urban open spaces, one can argue that the seeds are originating from cultivated individuals or garden refuge; however, the fact that it also occurs in rangelands and riparian areas in agricultural areas indicates that it can reproduce independently and that it has acquired a successful dispersal vector.

\section{Taxonomic treatment}

Celtis sinensis Pers., Syn. Pl. 1: 292 (1805); Spach, Ann. Sci. Nat., Bot. ser 2:t.16: 37 (1841); Benth., Fl. Hongk.: 324 (1861); Schltr., Bot. Jahrb. Syst. 36: 33 (1905). Celtis tetrandra Roxb. subsp. sinensis (Pers.) Y.C.Tang, Acta Phytotax. Sin. 17: 51
(1979). Type: Specimen cultivated in Cel's garden, Persoon (herbarium not designated).

Celtis sinensis Willd., nom. illeg.

Sponia sinensis Decne., nom. inval.

Celtis willdenowiana Roem. \& Schult., Syst. Veg. 6: 306 (1820). Sponia willdenowiana (Roem. \& Schult.) G. Don, Hort. Brit., 3: 610 (1839). Type: China, Willdenow, s.n. (B, holo.).

Celtis japonica Planch. in Prodr. 17: 172 (1873). Celtis sinensis Pers. var. japonica (Planch.) Nakai, Bot. Mag. Tokyo 28: (264) (1914). Type: Japan. Nagasaki. Oldham 722 (MPU, P, syn.); Yokohama, Maximowicz, s.n. (P, syn.); Japan, Wright, s.n. (P, syn.); China, Macao, Callery 20 (P, syn.).

Celtis nervosa Hemsl., J. Linn. Soc., Bot. 26(177): 450 (1894). Type: Taiwan, Apes Hills, Playfair 458 (K, holo.).

Celtis bodinieri H. Lév., Repert. Spec. Nov. Regni Veg. 13: 265 (1914). Type: China, Bodinier 1633, 2587 (E, A, syn.).

Celtis cercidifolia C.K. Schneid., Pl. Wilson 3(2): 276 (1916). Type: China, Ichang, Henry 2262 (A, holo.; GH, NY, iso.).

Celtis labilis C.K. Schneid., Pl. Wilson 3(2): 267 (1916). Type: China, Hubei, Changyang Xian, Wilson 444 (A, holo.; GH, K, CAS, iso.).

Celtis hunanensis Hand.-Mazz., Anz. Akad. Wiss. Wien, Math.-Naturwiss. K1., 59(7): 53 (1922). Type: China, Hunan, Lengshuijiang, Handel-Mazzetti 11968 (WU, holo.; A, iso.).

Celtis sinensis Pers. var. japonica Planch. forma purpurascens Nakai, Fl. Sylv. Kor. 19: 66 (1932). Type: Keinan, Mt. Mirokusan peninsulae Tôei, Nakai 11029 (TI, holo.).

Description: Deciduous tree up to $20 \mathrm{~m}$ tall; bark smooth, grey; branchlets flexuose, brown or pale grey-brown, covered in lenticels, pubescent, sometimes glabrescent late in the season; winter buds brown, $1 \mathrm{~mm}-3 \mathrm{~mm}$ long, glabrous. Leaves alternate, with stipules linear to lanceolate, $3 \mathrm{~mm}-5 \mathrm{~mm}$ long, fugacious; petioles $3 \mathrm{~mm}-10 \mathrm{~mm}$ long, pubescent, adaxial with a broad and shallow furrow; leaf blade ovate to ovate lanceolate or obliquely ovate, $30 \mathrm{~mm}-100 \mathrm{~mm} \times 35 \mathrm{~mm}-60 \mathrm{~mm}$; apex acute to shortly acuminate; base rounded, obtuse, obliquely truncate, asymmetrical, with three main veins; margin subentire to crenate in upper half, teeth $0-16$ on each side, lower margin entire; thickly papery; adaxial surface glossy dark green, glabrous or becomes scabrous with age; abaxial surface light green, glabrous or puberulent. Flowers inconspicuous, male or bisexual; pedicles $4 \mathrm{~mm}-12 \mathrm{~mm}$ long; greenish. Bisexual flowers $1-3$ in axils near the tip of the branch; perianth $\pm 2 \mathrm{~mm}$ long, stamens 4 ; ovary $1.5 \mathrm{~mm}-3.0 \mathrm{~mm}$ long, stigma hairy, divided into two, whitish. Male flowers fascicled. Fruit a drupe, 1(-3) per axil, globose 
TABLE 3: Number of individuals $>1.5 \mathrm{~m}$ and saplings $(<1.5 \mathrm{~m})$ of $C$. sinensis compared to a co-occurring indigenous relative and an invasive alien across land-cover types.

\begin{tabular}{|c|c|c|c|c|c|c|c|c|c|}
\hline \multirow[t]{2}{*}{ Land-cover types } & \multicolumn{2}{|c|}{ Celtis africana } & \multirow[t]{2}{*}{ Saplings } & \multicolumn{2}{|c|}{ Celtis sinensis } & \multirow[t]{2}{*}{ Saplings } & \multicolumn{2}{|c|}{ Melia azedarach } & \multirow[t]{2}{*}{ Saplings } \\
\hline & Adults & Stems per hectare & & Adults & Stems per hectare & & Adults & Stems per hectare & \\
\hline Gardens & 7 & 18 & 34 & 58 & 145 & 300 & 12 & 30 & 43 \\
\hline Open space & 11 & 28 & 30 & 31 & 78 & 72 & 125 & 313 & 1146 \\
\hline Riparian & 27 & 68 & 165 & 17 & 43 & 64 & 27 & 68 & 846 \\
\hline Rangeland & 105 & 263 & 398 & 14 & 35 & 56 & 39 & 98 & 511 \\
\hline Total & 150 & - & 627 & 120 & - & 492 & 203 & - & 2546 \\
\hline
\end{tabular}

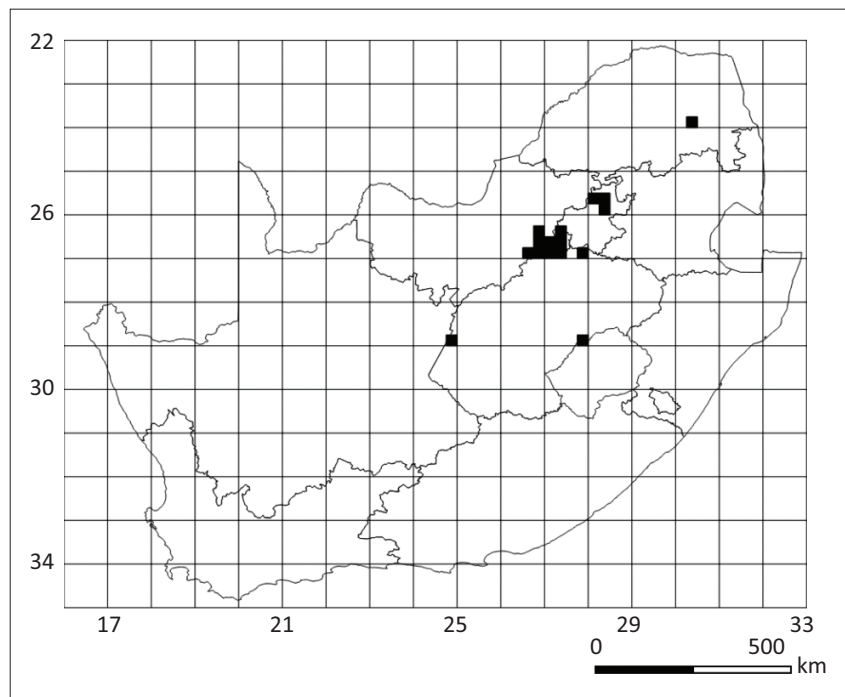

Source: E. van Rensburg, National Museum, Bloemfontein

FIGURE 3: Distribution map of Celtis sinensis in South Africa based on herbarium specimens and records from the South African Plant Invaders Atlas database.

or ovoid, $5-7(-8) \mathrm{mm}$ in diameter, green when immature turning yellow to reddish-brown when mature, becoming brown and wrinkled with age; stone white, sub-globose, surface texture reticulately foveolate.

Etymology: Celtis is a classical Latin name for the unrelated African species, Ziziphus lotus L., and sinensis indicates that the species originates from China (Clarke \& Charters 2016; Glen 2004).

Common names used for the tree in South Africa include Chinese nettle tree, Japanese hackberry, Chinese netelboom (Afr), po shu (Chinese), modutu (Setswana), lesika, mohatlakgomo, mogatakgomo (Sesotho). The Tswana name, modutu, means boredom and loneliness, suggesting that the dense shade of this tree is sought by people feeling bored.

Distribution: Celtis sinensis occurs on the Highveld of central South Africa (Figure 3) as a garden subject and has become naturalised in urban open spaces and riparian areas. It is generally sparsely distributed, but can form dense infestations in riparian areas and on roadsides. It is gradually colonising natural areas such as rangelands.

Phenology: Small, greenish flowers are present for a brief period during early spring. Fruits are produced in summer, but dried fruit can be present on the trees till late autumn.
Dispersal: Celtis sinensis reproduces with seeds, but also produces suckers. Its fleshy seeds are usually dispersed by animals (birds and bats) and by water run-off, or are dumped in urban open space as garden waste.

\section{Diagnostic characters}

Most Celtis species exhibit juvenile leaf morphology (Whittemore \& Townsend 2007) and long persistence thereof, which is different from the adult leaf morphology and makes it difficult to distinguish between young plants of C. africana, C. australis, C. occidentalis and C. sinensis. The shape and size of the leaves, number of teeth on the toothed margin, the extent to which the teeth extend along the margin to the leaf base, petiole length and the colour and size of the drupe show enough variability to distinguish between species in their juvenile state.

Celtis sinensis has dark green, ovate leaves (30 mm-100 mm $\times 35 \mathrm{~mm}-60 \mathrm{~mm}$ ) that are glossy above and softly hairy underneath. The leaves of $C$. australis are ovate-elliptic ( $50 \mathrm{~mm}-120 \mathrm{~mm} \times 15 \mathrm{~mm}-35 \mathrm{~mm}$ ), dark green and rough on the upper surface, but the lower surface is a lighter green and minutely hairy. Celtis africana leaves are ovate (15 mm-100 mm $\times 10 \mathrm{~mm}-50 \mathrm{~mm})$, very hairy on both surfaces and dark green when young, but adult leaves are dull green. Celtis occidentalis leaves are broadly ovate to cordate $(60 \mathrm{~mm}-130 \mathrm{~mm} \times 40-80 \mathrm{~mm})$, darker green and glossy above and softly hairy underneath.

The most conspicuous character by which juvenile plants of C. sinensis can be distinguished from C. africana, C. australis and $C$. occidentalis is the extent to which leaf margin is serrated (Figure 4). This variability is also contained in the adult leaf morphology. Celtis sinensis leaves are only toothed in the upper third towards the apex and have 8-16 teeth per side on the leaf margin. The leaf margin of C. africana is toothed more than two-thirds from the apex to the leaf base and generally has 14-22 teeth per side. Celtis australis has more than 20 teeth per side, and the margin is nearly completely toothed from the apex to near the base. Celtis occidentalis is also completely toothed down to the leaf base and commonly has 30-40 teeth per side.

The petiole length ranges from $3 \mathrm{~mm}$ to $7 \mathrm{~mm}$ for C. africana, from $3 \mathrm{~mm}$ to $10 \mathrm{~mm}$ for $C$. occidentalis and from $5 \mathrm{~mm}$ to $15 \mathrm{~mm}$ for both $C$. sinensis and C. australis. 


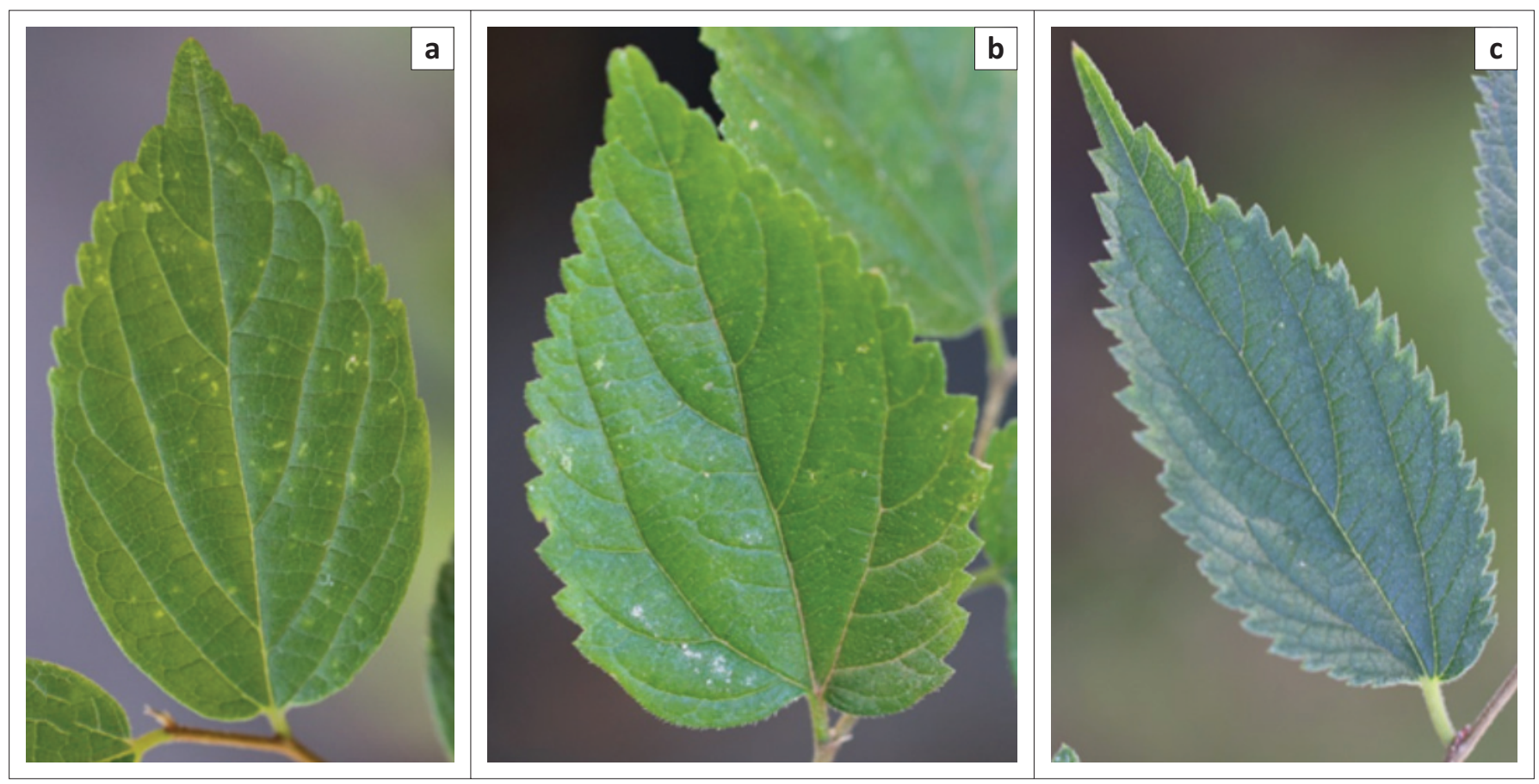

FIGURE 4: Sapling leaves of commonly sold 'stinkwood' trees at nurseries: (a) Celtis sinensis ( $\times 2.5)$, (b) Celtis africana ( $\times 2.5)$ and (c) Celtis australis ( $\times 1.5)$.

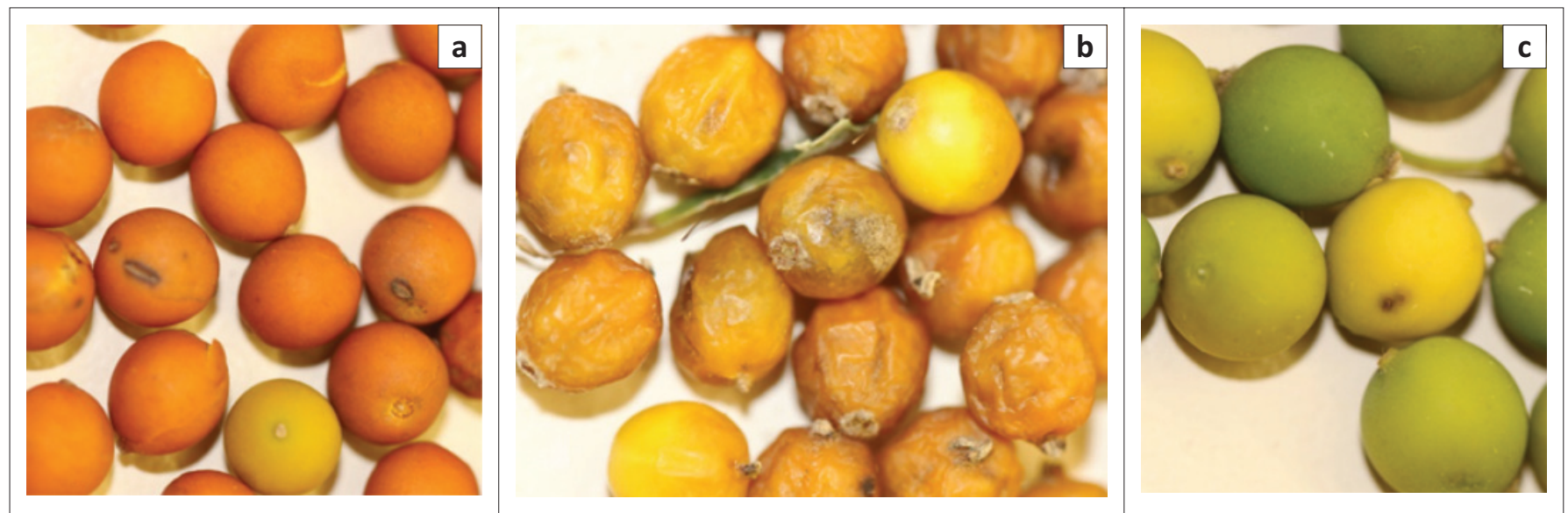

FIGURE 5: Fruit of (a) Celtis sinensis ( $\times 1.8)$, (b) Celtis africana $(\times 2.4)$ and (c) Celtis australis $(\times 2)$.

Fruit morphology and colour are also variable (Figure 5), but not a character of value to distinguish between saplings. Fruit of $C$. sinensis are glabrous and an ovoid $(5 \mathrm{~mm}-8 \mathrm{~mm})$ drupe, dark orange in colour and presented on short, stout stalks (4 mm-6 mm). Celtis australis fruit $(10 \mathrm{~mm}-12 \mathrm{~mm})$ are also ovoid and hairless, yellow-white turning purple-black when ripe and presented on long stalks (12 mm-14 mm). Celtis africana fruit ( $4 \mathrm{~mm}-6 \mathrm{~mm}$ ) are ovoid and glabrous, yellow turning brown and presented on long thin stalks (12 mm-14 mm). Celtis occidentalis has obovate or subglobose and dark orange fruit $(8 \mathrm{~mm}-11 \mathrm{~mm})$ turning purple-black when ripe and presented on long stalks.

Celtis sinensis is easily distinguishable from the indigenous C. gomphophylla and C. mildbreadii in that the leaf apex of C. gomphophylla is elongated into a distinct drip tip, which is almost a third of the leaf length, and from C. mildbraedii, which has a symmetric leaf base (apex of C. sinensis is elongated, but not into a distinctive drip tip, and the leaf base is asymmetrical).

\section{Key to juvenile plants commonly sold at nurseries}

1A. Lamina margin predominantly entire to dentate or serrate in apical third with $<17$ teeth per side...

C. sinensis

1B. Lamina margin predominantly dentate or serrate from apex to basal third, $>16$ teeth per side...

2

2A. Lamina margin predominantly with $>20$ teeth per side, lamina apex acute to caudate...

2B. Lamina margin rarely with $>20$ teeth per side, lamina apex predominantly acute to acuminate... C. africana

3A. Lamina ovate lanceolate to broadly ovate, lamina length and width $1.5: 1 \ldots$

C. occidentalis

3B. Lamina predominantly ovate lanceolate, lamina length and width $2: 1$ to $3: 1 \ldots$

C. australis 


\section{Key to adult specimens of Celtis in South Africa}

1A. Leaf apex elongate into a distinct drip tip, up to onethird of the leaf length ...

2

1B. Leaf apex elongate pointed, but not into a distinct drip tip ...

3

2A. Margin of leaf entire, base slightly asymmetric, leaf covered in minute and stiff hairs giving it a roughish feel; drupe conical-ovoid, $5 \mathrm{~mm}$ in diameter, mature fruit dark yellowish; distributed in KwaZulu-Natal and Eastern Cape in lowland and upland forests ...

C. gomphophylla

2B. Margin of leaf sharply serrated from base to apex or along the upper two-thirds of the leaf, base strongly asymmetric, leaf covered in spreading hairs giving it a velvety feel; drupe subglobose to pyriform, $10 \mathrm{~mm}-$ $12 \mathrm{~mm}$ in diameter, mature fruit dark brown almost black; distributed mainly in urban areas throughout South Africa ...

C. australis

3A. Leaf base cuneate and symmetric; fruit ovoid-ellipsoid, mature fruit red; distributed in Swaziland and KwaZuluNatal in isolated patches of lowland forests...

C. mildbreadii

3B. Leaf base rounded to cuneate or cordate and asymmetric; fruit globose or subglobose, mature fruit yellow to orange, brown or purplish ...

4

4A. Margin of leaf subentire to crenate along upper half of leaf, glossy dark green, ovate to ovate-elliptic, adaxial surface glabrous, but with hairs abaxially scattered along major veins and tufted in vein axils, leaf has a leathery, smooth surface; fruit $5 \mathrm{~mm}-8 \mathrm{~mm}$ in diameter; distributed mainly in urban areas throughout South Africa ...

C. sinensis

4B. Margin of leaf serrated along upper two-thirds of the leaf; dark green on both surfaces or paler beneath, narrowly to broadly ovate; velvety or roughish surface...

5

5A. Leaves broadly to narrowly ovate to ovate-elliptic, dark green in colour, sparingly to densely covered with hairs, leaf has a velvety surface; fruit $4 \mathrm{~mm}-6 \mathrm{~mm}$ in diameter; distributed throughout South Africa in all forests types, mesic savanna and wooded grassland ... $\quad$ C. africana

5B. Leaves ovate lanceolate to broadly ovate, dark green above, paler beneath, rough on the upper surface, smooth below; fruit $8 \mathrm{~mm}-11 \mathrm{~mm}$ in diameter; distributed mainly in urban areas throughout South Africa ... C. occidentalis

\section{Conclusion}

Celtis sinensis is commonly cultivated on the Highveld of central South Africa as a garden subject or street tree and is naturalised in urban open spaces and riparian areas. It is colonising rangelands of agricultural areas and should therefore be considered as a potential invasive species. It shows a similar population structure and dispersal corridors as the declared invasive, M. azedarach. Vegetative characters of the leaves and fruits distinguish accurately between indigenous and alien Celtis species, both for juvenile and adult trees. The findings of this study will sensitise the horticultural industry to the potential invasive threat of
C. sinensis and will inform the public on how to ascertain that white stinkwood purchased from nurseries are indeed C. africana.

\section{Specimens examined}

\section{Celtis africana}

SOUTH AFRICA. NORTH-WEST. - 2526 (Zeerust): Grasfontein, Lichtenburg, red sand, (-CC), 08 December 1929, Sutton 297 (PRE). 2626 (Klerksdorp): Renovaal, Klerksdorp, (-DD), 04 June 1975, De Feijter 232 (PUC). 2627 (Potchefstroom): North-West University, Potchefstroom, fence along botanical garden, (-CA), 11 October 2007, Siebert 3426; central town, roadside, Potchefstroom, (-CA), 18 November 2008, Lubbe \& Siebert 128 (PUC); North-West University, Potchefstroom, next to Totius Hall, (-CA), 07 February 2017, Komape 642 (PUC).

GAUTENG. - 2527 (Rustenburg): Uitkomst, Rustenburg, upper dam of Dunnungkamp, (-DD), 23 September 1970, Coetzee 259 (PUC). 2528 (Pretoria): Groenkloof, Pretoria, (-CA), 17 September 1904, Burtt-Davy 1980 (PRE); between Beestekraal and Vaalkop, Pretoria, at the bottom of hill, (-DC), 26 March 1978, Engelbrecht 2 (PRU). 2627 (Potchefstroom): Sterkfontein Caves, Isaac Stegmann Nature Reserve, Krugersdorp, (-BA), 06 September 1974, Mogg 36196 (PRE).

FREE STATE. - 2627 (Potchefstroom): Vredefort Dome, Parys, (-CD), January 2002, Cilliers 3008 (PUC). 2727 (Kroonstad): Valsch River, (-CA), October 1928, Pont 390 (PRE). 2827 (Senekal): Ferrara, Senekal, stone hills, (-AD), 18 December 1931, Goossens 993 (PRE). 2926 (Bloemfontein): Grantsheuwel, Bloemfontein, (-AA), 21 October 1967, Hanekom 969 (PRE);

\section{Celtis mildbraedii}

SOUTH AFRICA. KWAZULU-NATAL. - 2930 (Pietermaritzburg): Howard College, Durban, Stella Bush, (-CD), 05 November 1955, Bayer 2 (PRE); Stella Bush, Durban, (-CD), 20 July 1969, Strey 8785 (PRE); Inanda Mission Reserve, Matabetulu Area, just above Mzinyathi River confluence, (-DB), 10 August 1993, Ward 12388 (PRE). 3030 (Port Shepstone): Amanzimtoti, forest in river valley, (-BB), 17 December 1966, Ward 5905 (PRE);

\section{Celtis gomphophylla}

SOUTH AFRICA. KWAZULU-NATAL. - 2732 (Ubombo): $27 \mathrm{~km}$ south of Ingwavuma, Lebombo Range, Gwalaweni Forest, (-AC), 05 March 1973, White 10431 (PRE). 2831 (Nkandla): Ngoya Forest, Zululand, next to road in forest, (-DC), 12 February 1979, Van Wyk 2540 (PRU). 2832 (Mtubatuba): Monzi Golf Course, Mtubatuba district, Zululand, (-AD), 01 October 1976, Jacobsen 4710 (PRE). 3030 (Port Shepstone): Vernon Crookes Nature Reserve, forest on streambank, (-BC), 10 April 1986, Ward 9887 (PRE). 
3130 (Port Edward): Fish Eagle trail, Umtamvuna Nature Reserve, forest, (-AA), 23 April 1989, Abbott 4357 (PRU).

EASTERN CAPE. - 3129 (Port St Johns): 3 miles from Port St. Johns on road to Lusikisiki, forest, (-DA), 21 May 1970, Jenkins 13 (PRE).

\section{Celtis australis}

SOUTH AFRICA. NORTH-WEST. - 2627 (Potchefstroom): North-West University, Potchefstroom, parking area, (-CA), 26 September 2007, Siebert 3392 (PUC); central town, roadside, Potchefstroom, (-CA), 18 November 2008, Lubbe $\mathcal{E}$ Siebert 130 (PUC); North-West University, Potchefstroom, parking area next to building G15, (-CA), 07 February 2017, Komape 643 (PUC); Suikerbos Nature Reserve, Venterskroon, (-CC), 17 November 2011, Komape, Mabe E Siebert 205 (PUC);

GAUTENG. - 2528 (Pretoria): Union Building, Pretoria, (-CB), 21 June 1984, Du Plessis 75 (PRU); Elarduspark, in garden around church building, (-CD), 23 October 2012, Van Greuning 903 (PRU).

\section{Celtis occidentalis}

CANADA. ONTARIO. - Lanark County, Elmsley, Smith's Fall, hydro park, along river on grassy banks, 22 August 1945, Senn E Barnsley 2888 (PRU).

USA. MISSISSIPPI. - Jasper County, along small rocky streams near Webb. City, 16 October 1922, Palmer 22313 (PRE). PENNSYLVANIA. - Crawford County, woods, along small streams near Pittsburg, 20 April 1922, Palmer 20833 (PRE). WEST VIRGINIA. - Wirt County, top of Bonnette's hill below upper gap. About one mile up Little Kanawha River from Palestine, 02 September 1941, Bartholomew s.n. (PRE).

\section{Celtis sinensis}

SOUTH AFRICA. LIMPOPO. - 2330 (Tzaneen): Bonlati, Tzaneen, in mixed lowveld/bushveld, (-CD), 28 April 2002, Prinsloo 786 (PRU).

NORTH-WEST. - 2627 (Potchefstroom): North-West University, Potchefstroom, parking area, (-CA), 19 September 2007, Siebert 3376 (PUC); central town, Potchefstroom, roadside, (-CA), 18 November 2008, Lubbe \& Siebert 129 (PUC); Albert Luthuli Street, Potchefstroom, next to Wasgoed Stream, (-CA), 06 Oct 2011, Komape, Mabe E Siebert 9 (PUC); North-West University, Potchefstroom, parking area next to building E4, (-CA), 07 February 2017, Komape 644 (PUC).

GAUTENG. - 2528 (Pretoria): Salvokop residential area, Pretoria, 3rd Avenue, behind station, (-CA), 28 September 2002, Siebert \& Siebert 2031 (PRU); Elardus Park, Pretoria, planted in garden, (-CD), 23 October 2012, Van Greuning 902 (PRU).

FREE STATE. - 2627 (Potchefstroom): Sasolburg, Plot 12, Wonderfontein Rd, (-DD), 27 September 1997, Kroon 15291 (NMB).
CHINA. - Pai Ying Tung, Lao Shan, 14 July 1930, Chiao 2750 (PRE); Tai Ching Kung, Lao Shan, 14 August 1930, Chiao 2954 (PRE).

\section{Acknowledgements}

Mr Chris van Niekerk and Mr Hardus Cloete cultivated Celtis species in the North-West University Botanical Garden for comparative purposes. Ms Elmarie van Rensburg of the National Museum, Bloemfontein, provided the distribution map. The directors and curators of the cited herbaria are acknowledged for giving access to the study material. Keys were widely tested by field botanists in South Africa.

\section{Competing interests}

The authors declare that they have no financial or personal relationships that may have inappropriately influenced them in writing this article.

\section{Authors' contributions}

S.J.S. planned and coordinated the study and wrote the manuscript. M.S. contributed to the writing of the manuscript and was responsible for the construction of the key to the indigenous and cultivated Celtis species and the nomenclature and description of Celtis sinensis. L.K. contributed tree survey data and analysed the population data. D.M.K. collected field data and contributed to the writing of the manuscript.

\section{References}

Bentham, G., 1861, Flora hongkongensis: A description of the flowering plants and ferns of the island of Hongkong, L. Reeves, London.

Botha, J., Witkowski, E.T.F. \& Shackleton, C.M., 2004, 'The impact of commercial harvesting on Warburgia salutaris ("pepper-bark tree") in Mpumalanga, South Africa', Biodiversity \& Conservation 13(9), 1675-1698. https://doi.org/10.1023/ B:BIOC.0000029333.72945.b0

Buck, G.W. \& Bidlack, J.E., 1998, 'Identification of Quercus and Celtis species using morphological and electrophoretic data', Proceedings of the Oklahoma Academy of Science 78, 22-23.

Cilliers, S.S. \& Bredenkamp, G.J., 1999, 'Ruderal and degraded natural vegetation on vacant lots in the Potchefstroom Municipal Area, North West Province, South Africa', South African Journal of Botany 65(2), 163-173. https://doi.org/10.1016/ S0254-6299(15)30956-X

Clarke, H. \& Charters, M., 2016, The illustrated dictionary of southern African plant names, ABC Press, Cape Town.

Davoren, E., Siebert, S.J., Cilliers, S.S. \& Du Toit, M.J., 2016, 'Influence of socioeconomic status on design of Batswana home gardens and associated plant diversity patterns in northern South Africa', Landscape and Ecological Engineering 12, 129-139. https://doi.org/10.1007/s11355-015-0279-x

Department of Environmental Affairs, 2014, National Environmental Management Biodiversity Act 2004 (Act No. 10 of 2004) Alien and Invasive Species Lists, Government Gazette of South Africa, Pretoria, pp. 3-80.

Don, G., 1839, Sweet's Hortus Britannicus or, a catalogue of all the plants indigenous or cultivated in the gardens of Great Britain, arranged according to the natura system, James Ridgway, London.

Fu, L.-K., Chen, C.J. \& Tang, Y.C., 1979, 'Materiae ad floram Ulmacearum Sinensium', Acta Phytotaxonomica Sinica 17(1), 14-52.

Glen, H., 2004, What's in a name?, Jacana, Johannesburg.

Glen, H. \& Van Wyk, B., 2016, Guide to trees introduced into southern Africa, Struik Nature, Cape Town.

Handel-Mazzetti, H.R.E., 1922, 'Sitzung der mathematisch-naturwissenschaftlichen klasse vom 9 März 1922', Anzeiger/Akademie der Wissenschaften in Wien, Mathematisch-Naturwissenschaftliche Klasse 59(7), 47-59.

Hemsley, W.B. \& Forbes, F.B., 1894, 'An enumeration of all the plants known from China proper, Formosa, Hainan, the Corea, the Luchu archipelago, and the island of Hong Kong, together with their distribution and synonym', Journal of the Linnean Society, Botany 26(177), 307-456.

Henderson, L., 1998, 'Southern African Plant Invaders Atlas (SAPIA)', Applied Plant Sciences 12, 31-32. 
Henderson, L., 2001, Alien weeds and invasive plants: A complete guide to declared weeds and invaders in South Africa, PPRI Handbook 12, Agricultural Research Council, Pretoria.

Henderson, L., 2007, 'Invasive, naturalized and casual alien plants in southern Africa: A summary based on the Southern African Plant Invaders Atlas (SAPIA)', Bothalia 37(2), 215-248. https://doi.org/10.4102/abc.v37i2.322

Henderson, L. \& Cilliers, C.J., 2002, Invasive aquatic plants, Plant Protection Research Institute Handbook 16, ARC Plant Protection Research Institute, Pretoria.

Henderson, M., Fourie, D.M.C., Wells, M.J. \& Henderson, L., 1987, Declared weeds and alien invader plants in South Africa, Department of Agriculture and Water Supply, Pretoria.

Horvitz, N., Wang, R., Zhu, M., Wan, F.-H. \& Nathan, R., 2014, 'A simple modelling approach to elucidate the main transport processes and predict invasive spread: River-mediated invasion of Ageratina adenophora in China', Water Resources Research 50(12), 9738-9747. https://doi.org/10.1002/2014WR015537

Joffe, P., 2001, Creative gardening with indigenous plants, Briza, Pretoria.

Kalwij, J.M., Milton, S.J. \& McGeoch, M.A., 2008, 'Road verges as invasion corridors? A spatial hierarchical test in an arid ecosystem', Landscape Ecology 23(4), 439451. https://doi.org/10.1007/s10980-008-9201-3

Kuruneri-Chitepo, C. \& Shackleton, C.M., 2011, 'The distribution, abundance and composition of street trees in selected towns of the Eastern Cape, South Africa', Urban Forestry \& Urban Greening 10(3), 247-254. https://doi.org/10.1016/ Urban Forestry \&

Le Maitre, D.C., Van Wilgen, B.W., Gelderblom, C.M., Bailey, C., Chapman, R.A. \& Nel, J.A., 2002, 'Invasive alien trees and water resources in South Africa: Case studies of the costs and benefits of management', Forest Ecology and Management 160 143-159. https://doi.org/10.1016/S0378-1127(01)00474-1

Léveillé, H., 1914, 'Decades plantarum novarum', Repertorium Specierum Novarum Regni Vegetabilis 13(363-367), 257-266. https://doi.org/10.1002/fedr.19140 131702

Lonsdale, W.M., 1999, 'Global patterns of plant invasions and the concept of invisibility', Ecology 80, 1522-1536. https://doi.org/10.1890/0012-9658(1999)080 [1522:GPOPIA]2.0.CO;2

Lubbe, C.S., Siebert, S.J. \& Cilliers, S.S., 2011, 'A floristic analysis of domestic gardens in the Tlokwe Municipal area, South Africa', Bothalia 41(2), 351-361. https://doi. org/10.4102/abc.v41i 2.78

Mgidi, T.N., Le Maitre, D.C., Schonegevel, L., Nel, J.L., Rouget, M. \& Richardson, D.M., 2007 , 'Alien plant invasions - Incorporating emerging invaders in regiona prioritization: A pragmatic approach for Southern Africa', Journal of Environmental Management 84(2), 173-187. https://doi.org/10.1016/j.jenvman.2006.05.018

Milton, S.J. \& Dean, W.R.J., 1998, 'Alien plant assemblages near roads in arid and semiarid South Africa', Diversity and Distributions 4, 175-187. https://doi.org/10.1046/ j.1472-4642.1998.00024.x

Molebatsi, L.Y., Siebert, S.J. \& Cilliers, S.S., 2013, 'Alien and indigenous plant species diversity of homegardens of a rural settlement in the eastern Kalahari, South Africa', Scripta Botanica Belgica 50, 294-303.

Nakai, T., 1914, 'Japanese Celtis', The Botanical Magazine Tokyo 28(330), 261-306. https://doi.org/10.15281/jplantres1887.28.330_261

Nakai, T., 1932, Flora Sylvatica Koreana 19, Forestal Experiment Station, Government General of Chosen, Keijo.
Ndhlovu, T., Milton, S.J. \& Esler, K.J., 2016, 'Impact of Prosopis (mesquite) invasion and clearing on vegetation species composition and diversity in semi-arid Nama-Karoo rangeland, South Africa', African Journal of Range and Forage Science 33(2), rangeland, South Africa', African Journal of Range and Ford
101-110. https://doi.org/10.2989/10220119.2016.1184181

Persoon, C.H., 1805, Synopsis Plantarum 1, C.F. Cramerum, Parisiis Lutetiorum.

Planchon, J.E., 1873, 'Ulmaceae', in A. de Candolle (ed.), Prodromus Systematis Naturalis Regni Vegetabilis 17, pp. 151-210, Masason, Paris.

Pooley, E., 1997, The complete fields guide to trees of Natal, Zululand and Transkei, Natal Flora Publications Trust, Durban.

Roemer, J.J. \& Schultes, J.A., 1820, Caroli a Linné. Systema vegetabilium: Secundum classes, ordines, genera, species. Cum characteribus differentiis et synonymis. Editio nova, speciebus inde ab editione XV. Detectis aucta et locupletata 6, ed. 15 bis, Sumtibus J. G. Cottae, Stuttgardtiae.

Sargent, C.S., 1916, Plantae Wilsonianae; an enumeration of the woody plants collected in western China for the Arnold arboretum of Harvard university during the years 1907, 1908, and 1910, by E. H. Wilson, 3(2), The University Press, the years 190.

Schlechter, R., 1905, 'Pflanzengeographische Gliederung der Insel Neu-Calenonien', Botanische-Jahrbücher für Systematik, Pflanzengeschichte und Planzengeographie 36, 4-14.

Scott, D.W., 2009, 'Sturges' rule', Wiley Interdisciplinary Reviews: Computational Statistics 1(3), 303-306. https://doi.org/10.1002/wics.35

Seebens, H., Blackburn, T.M., Dyer, E.E., Genovesi, P., Hulme, P.E., Jeschke, J.M. et al., 2017 , 'No saturation in the accumulation of alien species worldwide', Nature Communications 8, 1-9, https://doi.org/10.1038/ncomms14435

Shackleton, C.M., 1993, 'Demography and dynamics of the dominant woody species in a communal and protected area of the eastern Transvaal Lowveld', South African Journal of Botany 59, 569-574. https://doi.org/10.1016/S02546299(16)30672-X

Spach, E., 1841, 'Revisio Celtidum Genuinarum', Annales des sciences naturelles. Botanique. ser 2:t.16, 34-42.

Stirton, C.H., 1978, Plant invaders beautiful but dangerous, Department of Nature Conservation of the Cape Provincial Administration, Cape Town.

Venter, S.M. \& Witkowski, E.T.F., 2010, 'Baobab (Adansonia digitata L.) density, sizeclass distribution and population trends between four land-use types in northern Venda, South Africa', Forest Ecology and Management 259(3), 294-300. https:// doi.org/10.1016/j.foreco.2009.10.016

Vitousek, P.M., D'Antonio, C., Loope, L.L., Rejmanek M. \& Westbrooks, R., 1997, 'Introduced species: A significant component of human-caused global change', New Zealand Journal of Ecology 21, 1-16.

Wells, M.J., Balsinhas, A.A., Joffe, H., Engelbrecht, V.M., Harding, G. \& Stirton, C.H., 1986, 'A catalogue of problem plants in southern Africa', Memoirs of the Botanical Survey of South Africa 53, Botanical Research Institute, Pretoria.

Whittemore, A.T. \& Townsend, A.M., 2007, 'Hybridization and self-compatibility in Celtis: AFLP analysis of controlled crosses', Journal of the American Society of Horticultural Science 132(3), 368-373.

Wiegand, K., Ward, D., Thulke, H.H. \& Jeltsch, F., 2000, 'From snapshot information to long-term population dynamics of Acacias by a simulation model', Plant Ecology 150(1-2), 97-114. https://doi.org/10.1023/A:1026574303048

Wild, H., 1961, 'Harmful aquatic plants in Africa and Madagascar', Kirkia 2, 1-66. 